DOI 10.31558/2519-2949.2021.3.9

УДК 321.01:316.36-057.875(477+478)

ORCID ID: https://orcid.org/0000-0003-2933-3186

Осін В. В., Національний технічний університет "Дніпровська політехніка"

\title{
ГЕНДЕРНІ АСПЕКТИ НАВЧАННЯ СТУДЕНТІВ ТА СТУДЕНТОК ПОЛІТОЛОГІЧНИХ СПІЛЬНОТ УКРАЇНИ І МОЛДОВИ
}

Стаття присвячена виявленню гендерних аспектів навчання студентів та студенток політологічних спільнот України (Львів, Харків, Сімферополь) і Молдови (Кишинів) у період 20122013 рр. Робота є частиною масштабнішого дослідження, яке фіксує стан української політології y 2012-2013 рр. і дозволяе краще зрозуміти особливості політичних, соціальних, етнічних, економічних, гендерних та дисциплінарних уявлень студентства напередодні подій Революиії гідності. Емпіричним базисом статті є результати опитування студентів та студенток I-V курсів, що навчалися за спеціальністю «Політологія» на бакалаврів, спеціалістів та магістрів у Львівському начіональному університеті імені Івана Франка, Харківському національному університеті імені В. Н. Каразіна, Таврійському наиіональному університеті імені В. І.Вернадського та Державному університеті Молдови.

Відповіді респондентів дозволяють виділити декілька тенденщій. По-перше, студенти та студентки найчастіше стикаються з різними форми дискримінації на старших курсах. По-друге, відсоток студенток, які зіткнулися з різними формами дискримінаиії в академічному середовищі вище за аналогічний показник серед студентів. По-третє, слід вказати на те, щчо в переважній більшості випадків респонденти відзначають одиничний характер відчутої ними безпосередньо дискриміначії, хоча дані різняться залежно від регіону та статі. Нарешті, найчастіше студенти та студентки зазнавали дискриміначії за політичними поглядами, щьо, напевно, зрозуміло, якщо брати до уваги спечіальність, місия і час проведення опитування.

У завершальній частині статті зроблено висновок про те, щњо в украӥнській та молдавській Академії низовий (базовий) студентський рівень передбачає краще ставлення до жінок, ніж до чоловіків. Враховуючи те, що набагато більше студентів погоджується з иим твердженням, ніж студенток, можемо тлумачити цюю тенденцію як прояв патріархату. Себто, коли студентки не вбачають кращого ставлення, а чоловіки вбачають, маємо справу з прихованим джерелом конфлікту.

Ключові слова: гендер, регіони Украӥни, Молдова, історія політичної науки, дискримінація, nampiapxam.

Стаття продовжує серію розвідок з дисциплінарної рефлексії, значимість яких в цілому визначається відсутністю надійних даних з історії регіонального студентського рівня вітчизняної політичної науки. Водночас актуальність дослідження саме гендерних проблем політологічних спільнот, вторячи Стенлі Ротману, Сйпріл Келлі-Восснер та Метью Восснеру, «грунтується на ідеї, що деякі люди заслуговують можливостей, які в іншому випадку були б їм недоступні, і що вища освіта має сприяти позитивним соціальним змінам» [10, с. 108]. Сформульована в такий спосіб актуальність на перший погляд здається нерелевантною українським реаліям. Так, дані Державної служби статистики [1] начебто демонструють відсутність обмежень для жінок у політичній науці. Мовиться про переважання бакалавринь, магістерок та спеціалісток на відповідних циклах навчання протягом останніх 16 років. Зокрема, мінімальна за цей період гендерна різниця 2005/2006 навчального року (менше піввідсотка на користь дівчат-бакалаврів) буквально за п’ять років змінилась їхнім більш ніж $19 \%$ переважанням 2010/2011 навчального року. Після цього спостерігається поступове пом'якшення гендерного диспаритету, і ця тенденція є достовірною також для магістерок та спеціалісток - за тим винятком, що пік їхньої кількісної переваги припав на 2012/2013 навчальний рік (рис. 1).

Проте фемінізація, кількісне переважання жінок в професії, не передбачає (справжньої) гендерної рівності; ба більше, вона може виявитись сумісною з певним різновидом патріархату. 


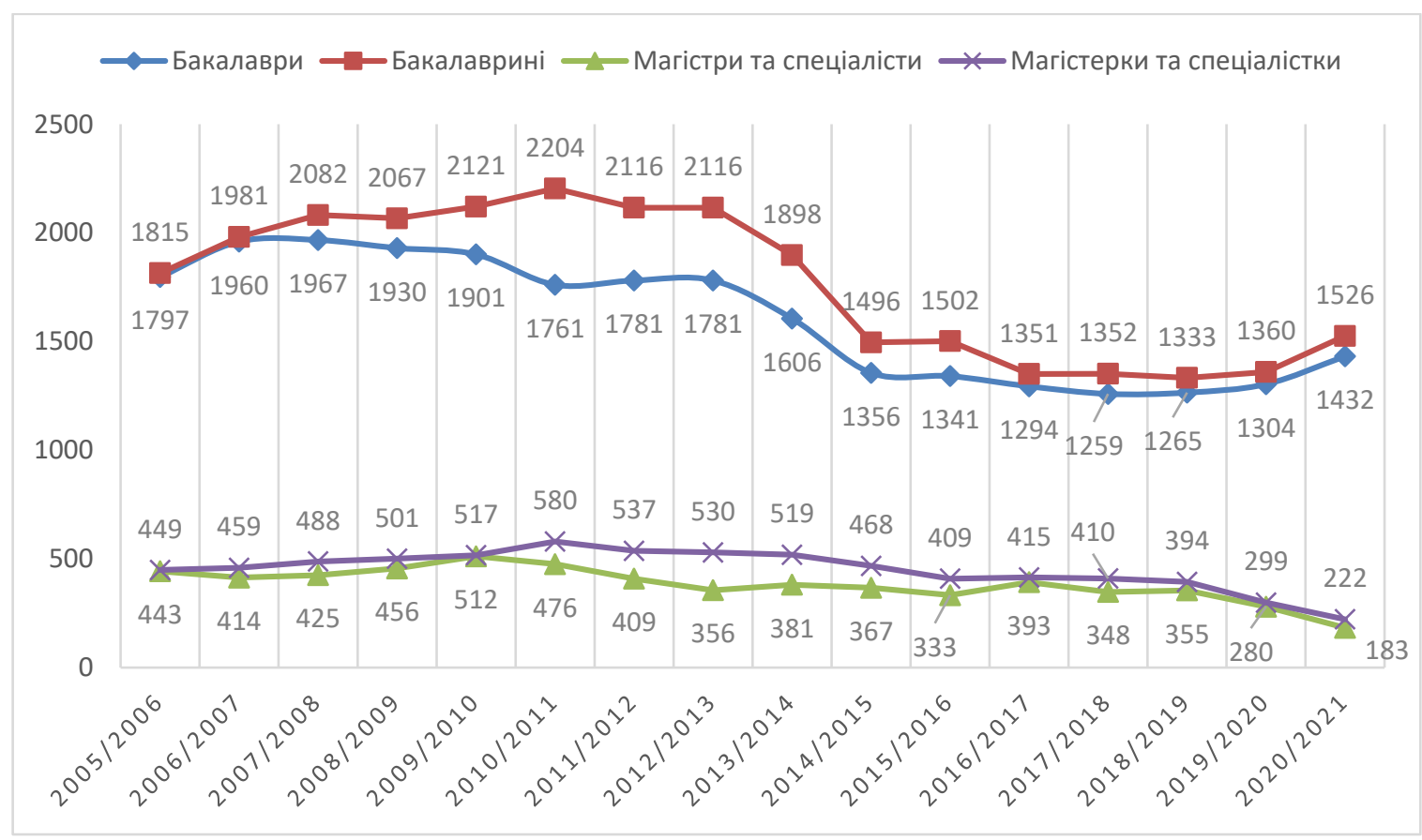

Рис. 1. Гендерний склад спеціальності «Політологія», 2005/2006-2020/2021 pp. [1]

Це було виявлено в одному з останніх досліджень стану української політології, виконаному на матеріалі гендерного розподілу кандидатських та докторських ступенів з політичних наук в 19962016 рр., а також інтерв'ю професорсько-викладацького складу трьох українських та одного молдавського вишів [6, 7]. Зазначалось, зокрема, що «фемінізація української політології не супроводжується деконструкцією патріархатної епістеми» [6, с. 49]. 3 одного боку, гендерна нерівність супроводжується «готовністю домінуючої - чоловічої - частини професії іiї ігнорувати, тривіалізувати або захищати» [7, с. 265]. 3 іншого боку, «усвідомлення політологинями власної цінності, як і раніше, формулюється в категоріях гендерних стереотипів й оцінюється 3 погляду встановлення гегемонії через освоєння гендерних ролей, що традиційно вважалися “чоловічими"» [6, c. 49]. Слід припустити, що виявлені патерни патріархату неможливі без комплементарних процесів на низовому, базовому або студентському рівнях. Врешті-решт, увага до цієї проблематики дозволить наблизитись до розуміння того, наскільки українську Академію можна розглядати як платформу гендерного примирення та/або поширення нових гендерних практик.

Мета роботи - виявлення гендерних аспектів навчання студентів та студенток політологічних спільнот України (Львів, Харків, Сімферополь) і Молдови (Кишинів) в період 2012-2013 рр. Дана робота $€$ частиною масштабнішого дослідження - українсько-молдавського проєкту (керівник Вадим Осін) з вивчення політики знання на пострадянському просторі. Грант був виділений Центром перспективних наукових досліджень і освіти в області соціальних і гуманітарних наук (CASE), Корпорацією Карнегі (Нью-Йорк) і Американськими радами з міжнародної освіти (ACTR/ACCELS) в рамках Програми «Соціальні трансформації в Прикордонні (Білорусь, Україна, Молдова )», Вільнюс, Литва). Це дослідження фіксує стан української політології в 2012-2013 pр. і дозволяє краще зрозуміти особливості політичних, соціальних, етнічних, економічних, гендерних та дисциплінарних уявлень студентства напередодні подій Революції гідності.

Аналіз останніх досліджень і публікацій. Гендер дедалі частіше опиняється в центрі уваги українських політологів та політологинь. Спектр інтересів є доволі різноманітним: від вивчення евристичного потенціалу цієї категорії в політології [5] до пояснення політичної економії національного будівництва [3], від дослідження гендерних проблем в Україні [4] або окремих сфер державного життя [9] до з'ясування гендерних аспектів процесу формування політичного іміджу [2]. Проте стан гендерної дисциплінарної рефлексії слід визнати незадовільним, зважаючи на майже повну (за винятком вже згадуваної роботи [6]) відсутність досліджень, виконаних у межах дисципліни. Ця розвідка є спробою заповнити наявну прогалину. 
Емпіричним базисом статті є результати опитування студентів та студенток I-V курсів, що навчалися за спеціальністю «Політологія» на бакалаврів, спеціалістів та магістрів у Львівському національному університеті імені Івана Франка (надалі ЛНУ), Харківському національному університеті імені В.Н. Каразіна (надалі ХНУ), Таврійському національному університеті імені В. I. Вернадського (надалі ТНУ) та Державному університеті Молдови (надалі ДУМ). Детальний опис методології міститься в колективній монографії [8], проте слід акцентувати увагу на двох моментах, обумовлених тим, що за основу анкети в гендерній частині був узятий опитувальник, використовуваний в останньому дослідженні думок членів американської Академії [10].

По-перше, було вирішено відмовитись від вимірювання дискримінаційних практик за допомогою складних шкал сумнівної валідності, замість чого автори сфокусувались на отриманні своєрідних самозвітів. У доцільності такого підходу переконують дослідження, що показують нездатність багатьох людей «адекватно оцінити факти прояву дискримінації і сексуальних домагань у кампусі» $[10$, с. 122$]$, що й обумовлює акцент на відповідних питаннях. По-друге, існують суттєві відмінності у сприйнятті гендерних проблем у межах пострадянської й американської систем вищої освіти. Йдеться, зокрема, про ухвалення у 1978 році Верховним судом США рішення, яке поклало початок свідомим i цілеспрямованим спробам підвищити рівень представленості різних меншин в найважливіших соціальних інститутах. Сказане стосувалося також жінок, і сьогодні «більшість освітніх асоціацій все ще мають відділи, присвячені покращенню статусу жінок в кампусі» [10, с. 113]. Їх успішність досить висока, оскільки молоде покоління студенток впевнене, що «ця війна вже виграна» [10, с.119], на доказ чого часто посилаються на переважний відсоток студенток в системі вищої освіти. Інституціоналізація викорінення дискримінації передбачає звичність публічного обговорення гендерних проблем. Однак для пострадянського вищої освіти інтерес до цієї проблематики досі здається надмірним і надуманим, в силу чого потрібно було (надто) обережно підходити i до вибору питань, i до самих їх формулювань. Врешті-решт, за погодженням 3 керівниками відповідних структурних підрозділів чотирьох 3ВО, де були проведені опитування студентів та студенток, частина питань, що традиційно використовуються (американськими) дослідниками для виявлення статевої дискримінації, були виключені з остаточного варіанту анкети. Це дещо знизило компаративні можливості опитування, зате відкрило шлях для проведення відповідного дослідження (треба визнати, що завідувачі кафедр часто мали всі підстави для своїх сумнівів, оскільки студенти та студентки, судячи з уточнюючих питань в ході анкетування, відчували певні незручності або навіть здивування з приводу доцільності вже наявних питань).

Отримати дані про гендерну дискримінацію планувалось за допомогою чотирьох питань, хоча в трьох випадках йдеться також і про інші форми дискримінації. Перше запитання: «Чи відчували Ви в університеті дискримінацію за ознакою статі, релігійних і політичних поглядів, сексуальної орієнтації або етнічного походження?». За позитивної відповіді пропонувалося перейти до іншого запитання: «На підставі чого Ви відчували дискримінацію?». Передбачались такі відповіді: «1) дискримінація за ознакою статі; 2) дискримінація за релігійними поглядами; 3) дискримінація за політичними поглядами; 4) дискримінація за сексуальною орієнтацією; 5) дискримінація за етнічним походженням; 6) інше (напишіть свій варіант відповіді)». Для всіх інших питань цього блоку використовувалися закриті варіанти відповідей. Третє запитання стосувалося масштабності: «Чи $\epsilon$ пережитий Вами вид дискримінації поодиноким випадком або систематичною проблемою?». Останнє запитання вимірювало ставлення до жінок: «Чи вважаєте Ви, що у Вашому університеті ставлення до студенток краще, ніж до студентів?».

Табл. 1, що узагальнює відповіді респондентів на перше запитання, дозволяє виявити дві головні тенденції. По-перше, студенти та студентки найчастіше стикаються з різними форми дискримінації на старших курсах. Найбільший «приріст» серед студентів був зафіксований у ЛНУ - майже 10 пунктів (3,7\% на молодших курсах vs. 13,51\% на старших). Найбільший «приріст» серед студенток спостерігався в ХНУ, і він майже вдвічі вищий за аналогічний показник серед студентів - 18,3 пунктів $(11,11 \%$ vs. $29,41 \%)$. В інших вишах різниця між молодшими та старшими курсами складає $2-3 \%$ як серед студентів, так і серед студенток. Важко сказати, з чим саме це пов'язано: з більш поблажливим ставленням до студентів та студенток на перших курсах, різним гендерним складом викладачів на молодших та старших курсах, засвоєнням певних цінностей, що дозволяють ідентифікувати дискримінаційні практики, що раніше проходили повз увагу, подальшою професійною соціалізацією, що створює напругу та конфлікти між студентами, студентками та викладачами тощо. Водночас, слід вказати на два винятки: у ТНУ релевантний відсоток студентів на молодших курсах на 2,4\% перевищує аналогічний показник старших курсів. Крім того, молдавські студентки не відчувають жодної дискримінації під час навчання. 
Відповіді політологів та політологинь на питання

«Чи відчували Ви в університеті дискримінацію за ознакою статі, релігійних і політичних поглядів, сексуальної орієнтації або етнічного походження?», \%

\begin{tabular}{|c|c|c|c|c|}
\hline & $T H Y$ & ЛНУ & ХНУ & $\begin{array}{c}\text { ДУМ } \\
\text { (м. Кишинів) } \\
\end{array}$ \\
\hline Студенти (I-II курс) & 16,67 & 3,7 & 13,33 & 13,33 \\
\hline Студенти (III-V курс) & 14,29 & 13,51 & 15,00 & 16,67 \\
\hline Усього студентів & 15,56 & 9,38 & 14,29 & 15,15 \\
\hline Студентки (I-II курс) & 16,67 & 11,11 & 11,11 & 0 \\
\hline Студентки (III-V курс) & 18,52 & 13,51 & 29,41 & 0 \\
\hline Усього студенток & 17,54 & 12,5 & 23,08 & 0 \\
\hline Усього студентів та студенток & 16,67 & 10,94 & 18,03 & 7,81 \\
\hline
\end{tabular}

По-друге, відсоток студенток, які зіткнулися з різними формами дискримінації в академічному середовищі вище за аналогічний показник серед студентів. Єдиний виняток - ДУМ, де на 15,15\% дискримінованих студентів не припадає жодної дискримінованої студентки. Серед студентів найрідше з тими чи іншими видами дискримінації стикаються в ЛНУ і ДУМ (10,94 \% і 7,81\% відповідно), тоді як в ХНУ і ТНУ - найчастіше (18,03 \% і 16,67 \% відповідно). Студентки найбільш очевидно дискримінуються в українських ЗВО, особливо в ХНУ $(23,08 \%)$ Відсоток дискримінованих студентів приблизно, в межах 14-15\%, однаковий для трьох політологічних спільнот (за винятком ЛНУ), тоді як показники студенток вельми різняться (особливо це стосується ДУМ). У цілому, більший ступінь дискримінації студенток не є несподіваним з огляду на раніше зафіксовані патерни патріархату, хоча потрібна подальша деталізація підстав дискримінації (політичні погляди, етнічне походження тощо).

Питання щодо підстав дискримінації обумовлено спостереженням наших американських колег, які, порівнюючи дані про дискримінацію серед студентів, адміністраторів і професорськовикладацького складу, виявили, що студент(к)и набагато більш позитивно оцінюють стан справ у цій галузі. Одне з висунутих авторами пояснень полягало в тому, що за останні десятиліття жінок стало більше серед студентів, тоді як серед професорсько-викладацького складу їх все ще порівняно небагато. Тому важко очікувати дискримінації там, де жінки є більшістю [10, с. 119] (це, вкупі 3 цілеспрямованими зусиллями щодо підвищення рівня представленості жінок в системі вищої освіти, дає іноді зворотний ефект. Наприклад, «принаймні, в області найму на роботу, чоловіки $\epsilon$, з точки зору професорсько-викладацького складу, найбільш защемленою (disadvantaged) групою в академії» [10, с. 128].) Відповідно, попередня гіпотеза передбачала наявність зв'язку між досвідом дискримінації і тим, хто саме переважає в політологічному співтоваристві, чоловіки або жінки. Зокрема, очікувалось, що в ТНУ (45 опитаних студентів і 58 опитаних студенток) жінки повинні рідше відчувати гендерну дискримінацію, ніж в ХНУ, де на 35 опитаних студентів припадало 26 студенток. Що стосується ЛНУ (рівне співвідношення опитаних студентів і студенток, по 64) і ДУМу (33 студента і 31 студентка), передбачалось, що в їхньому випадку дискримінація буде «розділена» приблизно порівну між чоловіками і жінками. Відповіді політологів та політологинь на питання щодо підстав безпосередньо пережитої дискримінації наводяться в табл. 2. Оскільки лише частина цієї таблиці відноситься безпосередньо до гендерної проблематики, надалі розглядатиметься «дискримінація за ознакою статі» і «дискримінації за сексуальною орієнтацією». Проте відзначу, що найчастіше студенти та студентки зазнавали дискримінації за політичними поглядами, що, напевно, досить логічно, якщо брати до уваги спеціальність, місця і час проведення опитування.

Стосовно гіпотези про залежність гендерної дискримінації та гендерного співвідношення в студентських середовищах, в цілому вона може бути прийнята, але з одним застереженням: відмінності між політологічними спільнотами не абсолютні, а відносні. Іншими словами, співвідношення студентів та студенток пояснює лише частину спостережуваних відмінностей в інтенсивності дискримінації. Якщо порівняти ХНУ і ТНУ, тобто дві спільноти з діаметрально протилежним статевим співвідношенням, то виявляється, що в ХНУ 75\% випадків дискримінації студенток за п'ятьма виділеними ознаками припадають на дискримінацію за ознакою статі - i жодного випадку статевої дискримінації студентів. У ТНУ, де студенток більше, останні хоча і стикаються з різноманітними формами дискримінації, але ось випадків утисків саме за ознакою статі 
Відповіді політологів та політологинь на питання «На підставі чого Ви відчували дискримінацію?», (\%)

\begin{tabular}{|c|c|c|c|c|c|c|}
\hline & $\begin{array}{c}\text { Дискримінація } \\
\text { за ознакою } \\
\text { статі }\end{array}$ & $\begin{array}{c}\text { Дискримінація } \\
\text { за релігійними } \\
\text { поглядами }\end{array}$ & $\begin{array}{c}\text { Дискримінація } \\
\text { за політичними } \\
\text { поглядами }\end{array}$ & $\begin{array}{c}\text { Дискримінація } \\
\text { за сексуальною } \\
\text { орієнтацією }\end{array}$ & $\begin{array}{c}\text { Дискримінація } \\
\text { за етнічним } \\
\text { походженням }\end{array}$ & Усього \\
\hline $\begin{array}{l}\text { Студенти } \\
\text { ТНУ }\end{array}$ & 0,0 & 0,0 & 62,5 & 12,5 & 25,0 & 100,0 \\
\hline $\begin{array}{l}\text { Студентки } \\
\text { ТНУ }\end{array}$ & 26,3 & 10,5 & 21,1 & 26,3 & 15,8 & 100,0 \\
\hline $\begin{array}{l}\text { Усього } \\
\text { студентів і } \\
\text { студенток } \\
\text { ТНУ }\end{array}$ & 18,5 & 7,4 & 33,3 & 22,2 & 18,5 & 100,0 \\
\hline $\begin{array}{l}\text { Студенти } \\
\text { ЛНУ }\end{array}$ & 20,0 & 20,0 & 10,0 & 40,0 & 10,0 & 100,0 \\
\hline $\begin{array}{l}\text { Студентки } \\
\text { ЛНУ }\end{array}$ & 11,1 & 22,2 & 22,2 & 22,2 & 22,2 & 100,0 \\
\hline $\begin{array}{l}\text { Усього } \\
\text { студентів і } \\
\text { студенток } \\
\text { ЛНУ }\end{array}$ & 15,8 & 21,1 & 15,8 & 31,6 & 15,8 & 100,0 \\
\hline $\begin{array}{l}\text { Студенти } \\
\text { ХНУ }\end{array}$ & 0,0 & 0,0 & 50,0 & 25,0 & 25,0 & 100,0 \\
\hline $\begin{array}{l}\text { Студентки } \\
\text { ХНУ }\end{array}$ & 75,0 & 0,0 & 0,0 & 0,0 & 25,0 & 100,0 \\
\hline $\begin{array}{l}\text { Усього } \\
\text { студентів і } \\
\text { студенток } \\
\text { ХНУ }\end{array}$ & 37,5 & 0,0 & 25,0 & 12,5 & 25,0 & 100,0 \\
\hline $\begin{array}{l}\text { Студенти } \\
\text { ДУМ }\end{array}$ & 0,0 & 16,7 & 50,0 & 0,0 & 33,3 & 100,0 \\
\hline $\begin{array}{l}\text { Студентки } \\
\text { ДУМ }\end{array}$ & 0,0 & 0,0 & 100,0 & 0,0 & 0,0 & 100,0 \\
\hline $\begin{array}{l}\text { Усього } \\
\text { студентів і } \\
\text { студенток } \\
\text { ДУМ }\end{array}$ & 0,0 & 12,5 & 62,5 & 0,0 & 25,0 & 100,0 \\
\hline $\begin{array}{l}\text { Усього } \\
\text { студентів та } \\
\text { студенток }\end{array}$ & 17,7 & 11,3 & 30,6 & 21,0 & 19,4 & 100,0 \\
\hline
\end{tabular}

менше, ніж в більш маскулінізованому середовищі ХНУ - 26,3\%. Не зайве вказати, що чоловіки за цим пунктом в ТНУ взагалі не дискримінуються. Те саме стосується дискримінації за сексуальною орієнтацією. Так, в ТНУ $26,3 \%$ випадків дискримінації студенток припадають на цей різновид утискань, що менше аналогічного показника для чоловіків, $12,5 \%$. Тоді як в ХНУ жодна студентка не вказала на цю проблему, а $25 \%$ випадків дискримінації студентів пов'язані саме 3 даною підставою. Єдина спільнота, де за статевою ознакою чоловіки стикаються з утиском, це ЛНУ, i сказане стосується також дискримінації за сексуальною орієнтацією. Так, сукупний відсоток цих двох типів дискримінації для студентів становить $60 \%$ - і майже вдвічі менше для жінок (33,33\%). I ці дані пояснити досить складно, враховуючи абсолютний паритет укількості опитаних студентів і студенток. Ще більш складно сказати щось певне щодо ДУМ, де взагалі не зафіксовано жодного випадку дискримінації за статтю чи сексуальною орієнтацією.

Нарешті, слід вказати на те, що в переважній більшості випадків респонденти відзначають одиничний характер відчутої ними безпосередньо дискримінації, хоча дані різняться залежно 
від регіону та статі (рис. 2). Найгірше в цьому сенсі було студенткам ТНУ та ХНУ, а також студентам ЛНУ. Оскільки саме формулювання питання не передбачало деталізації того, який саме вид дискримінації респонденти та респондентки оцінюють на предмет ії систематичності, потрібне зіставлення даних з різних питань. Зокрема, в ТНУ і ХНУ студентки, які зіткнулись $з$ дискримінацію за ознакою статі, в $80 \%$ і 100\% випадках відповідно вказують на їі системність. Схожі дані отримані і щодо дискримінації за сексуальною орієнтацією.

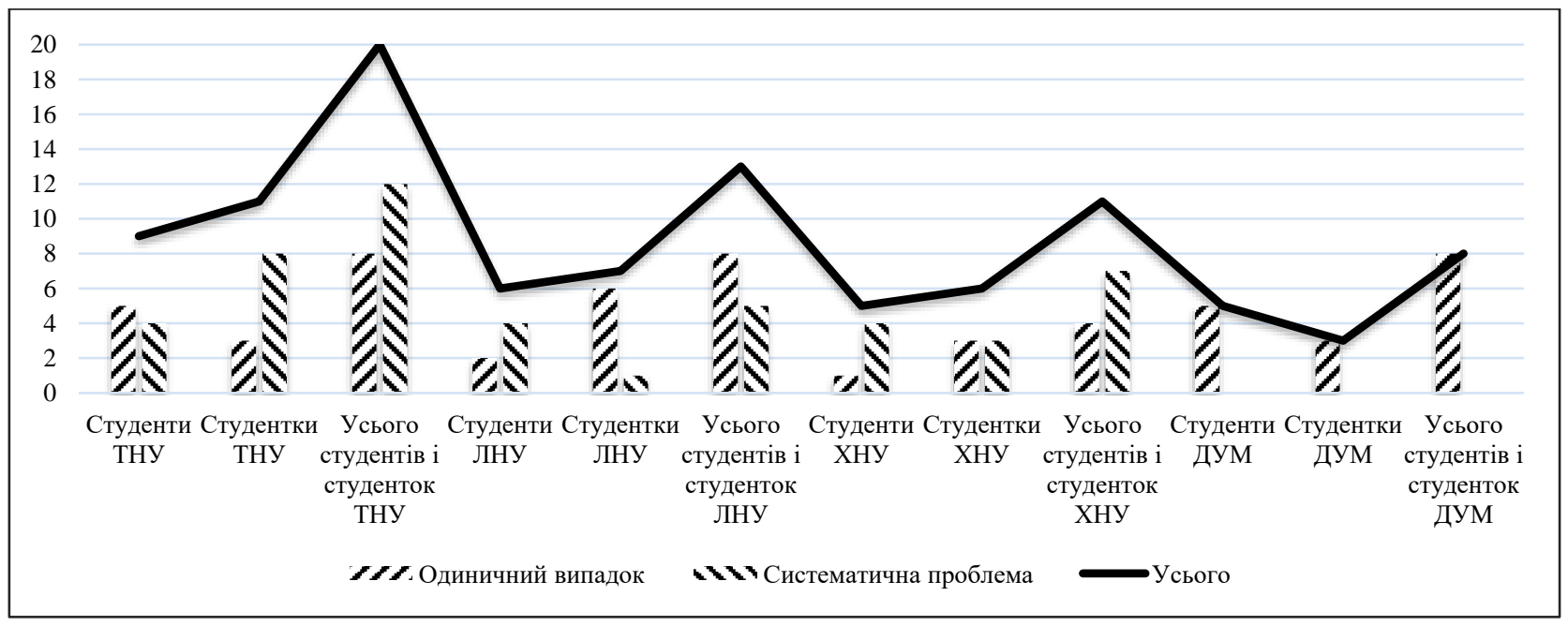

Рис. 2. Відповіді політологів та політологинь на запитання "Чи с пережитий Вами вид дискримінації поодиноким випадком або систематичною проблемою?"

Рис. 3 презентує відповіді респондентів на питання щодо різниці у ставленні до студенток та студентів. За його допомогою спочатку планувалось зрозуміти взаємовідносини між студентами i студентками в пострадянській Академії, а сама модель представлялася досить-таки прямолінійною: конфлікти і напруга супроводжуватиметься взаємними звинуваченнями сторін. Згодом, зафіксувавши наявність патріархату, я замислився над тим, які дані в результаті можуть бути отримані. I якщо з приводу відповідей студенток все було досить очевидно (патріархат не може не супроводжуватися визнанням пригнобленої сторони свого статусу), то щодо відповідей студентів все було заплутаніше. Теорія патріархату допускає кілька варіантів відповіді, від грайливого визнання високого статусу жінки до заперечення будь-яких преференцій. I в тому, i в іншому випадку насправді маскується мовчазне визнання винятковості чоловіка, який досягає успіху в рівних умовах або на правах переможця (i з позиції сили) дарує жінці її особливий статус. Проте жодне припущення не було правильним. Йдеться, зокрема, про відсутність протиріччя між студентками і студентами: обидві сторони сходяться в тому, що ставлення до жінок в їхньому університеті краще, ніж ставлення до чоловіків.

У сказаному впевнені 14,6\% студентів ТНУ, 23,3\% студентів ЛНУ, 25,7\% студентів ХНУ та 21,9\% студентів ДУМу. Так, в ЛНУ, на 7,8\% студенток, які відповіли позитивно на це питання, припадає аналогічний відсоток тих, хто відповів негативно. Але на відміну від схожої ситуації з ХНУ, частка жінок тільки втричі менше частки чоловіків. У випадку з ТНУ також мова йде про менш ніж трикратну перевагу студентів, які наполягають на кращому ставленні до студенток у стінах їхнього 3ВО, проте на 5,4\% студенток, які констатували краще до себе ставлення, доводиться «лише» 3,6\% тих, хто так не вважає. У цілому, відсоток студенток, які вважають, що до них ставляться краще, очевидно нижче показника для студентів, і різниця іноді сягає семиразових значень. Як, наприклад, в ДУМ, де максимальний відсоток студенток, згодних зі студентами в цьому питанні, складає 3,2\% проти майже $22 \%$ студентів. Або в ХНУ, де різниця ще більш показова (яскрава): $3,8 \%$ студенток vs $25,7 \%$ студентів. Останній приклад особливо цікавий: враховуючи, що саме в ХНУ фіксується найвищий відсоток студенток, які пережили релевантні форми дискримінації, відсутність асоційованих з цими практиками ставлення здається досить дивною. 3 іншого боку, значимим $є$ те, що найбільший відсоток студентів, переконаних у кращому ставленні до студенток, спостерігається в ЗВО, який характеризується найбільшою кількісною перевагою студентів та чоловіків-викладачів. 


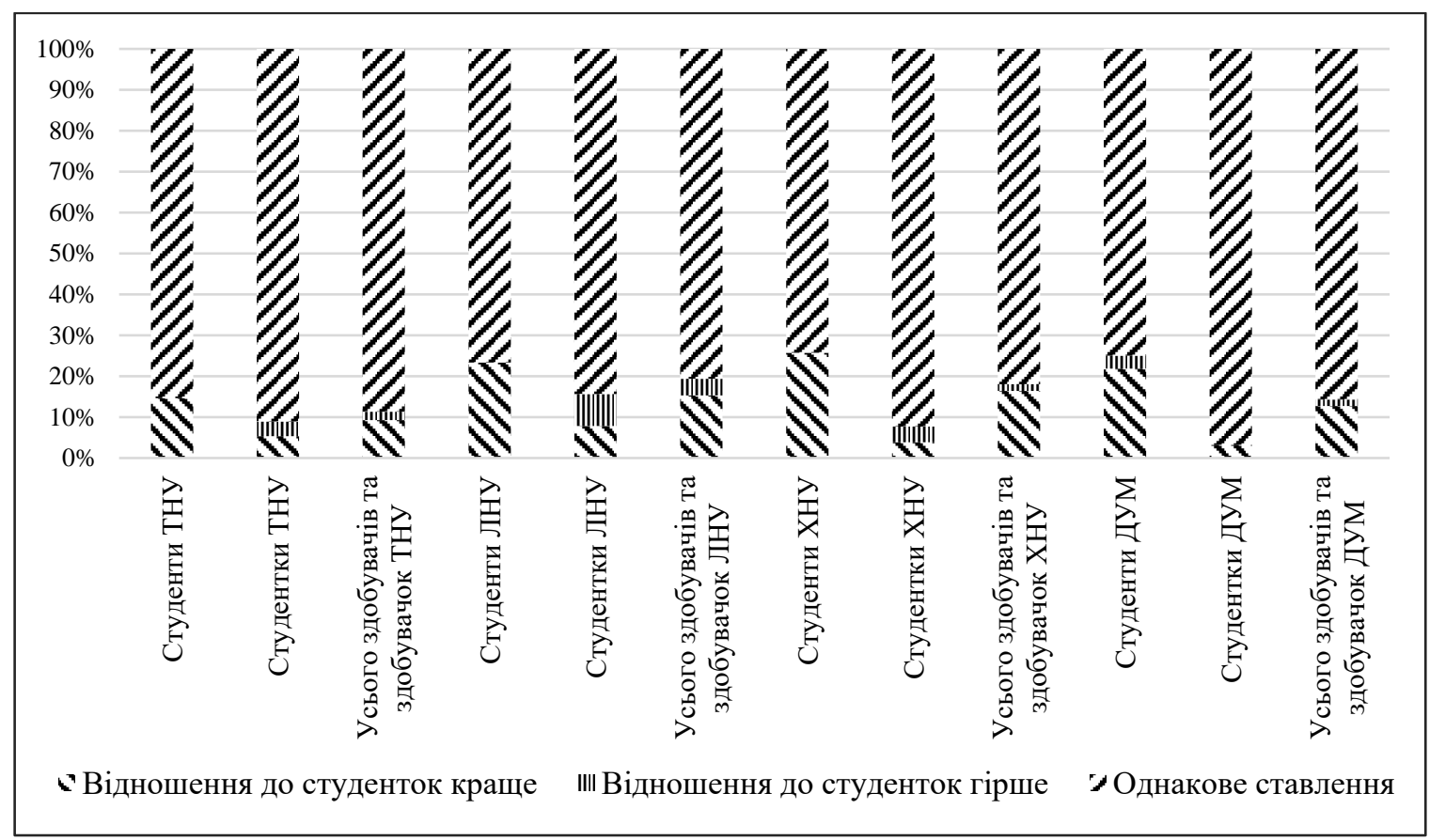

\section{Рис. 3. Відповіді політологів та політологинь на запитання \\ «Чи вважаєте Ви, що у Вашому університеті ставлення до студенток краще, ніж до студентів?» (\%)}

Тому відповідні показники слід інтерпретувати, передусім, як підтвердження раніше зафіксованих патернів патріархату, коли «домінуюча гендерна група виявлятиме надмірну чутливість до найменших тенденцій у традиційному розподілі гендерних ролей унауці, сперечаючись щодо легітимності самої постановки проблеми нерівності свосрідну спробу переважаючої частини» $[6$, с. 46].

Висновки. У даній статті здійснена спроба виявлення гендерних аспектів навчання студентів та студенток політологічних спільнот України і Молдови. Зокрема, з'ясовано, що в українській та молдавській Академії низовий (базовий), студентський рівень передбачає краще ставлення до жінок, ніж до чоловіків. Враховуючи обговорювану вище гендерно обумовлену різницю у відсотках, можемо тлумачити цю тенденцію як прояв патріархату. Тобто, коли студентки не вбачають кращого ставлення, а чоловіки вбачають, маємо справу з прихованим джерелом конфлікту. Ми позбавлені можливості запитати студентів, що саме вони розуміли під поняттям «краще ставлення», але цілком очевидний зв'язок між фемінізацією пострадянських соціальних наук на кандидатському рівні і сприятливим ставленням до студенток на попередньому, студентському етапі системи вищої освіти. Питання, що стосується фактора ${ }^{1}$ або факторів, що обумовлюють подібний, багато в чому суперечливий і парадоксальний зв'язок, який існує між, в марксистських термінах, базовим та надбудовним патріархатом в Україні та Молдові, потребує, звичайно, додаткового дослідження. Це планується здійснити в наступних дослідженнях.

\section{Бібліографічний список:}

1. Вища освіта в Україні. Демографічна та соціальна статистика / Освіта. Державна служба статистики України. URL: http://ukrstat.gov.ua/ (дата звернення: 11.05.2021)

2. Дідух Г. Я. Формування іміджу жінки-політичного лідера : автореф. дис. ... канд. політ. наук : 23.00.02. Київ, 2010. 20 с.

3. Журженко Т. Гендерные рынки Украины: политическая экономия национального строительства. Вильнюс: ЕГУ, 2008. 256 с.

4. Катан О. І. Концептуальні й політико-практичні засади вирішення гендерної проблеми в Україні : автореф. дис. ... канд. політ. наук : 23.00.02. Київ, 2005. 19 с.

5. Літвін Л. А. Особливості гендерних досліджень у політичній науці. Політологічні записки. 2013. № 7. URL: http://nbuv.gov.ua/UJRN/Polzap_2013_7_18 (дата звернення: 19.06.2021).

6. Осін В. Українська політологія в період фемінізації: боротьба «за» та «проти» патріархатної епістеми. 
Політичне життя. Вінниця, 2018. №4. С.44-51. DOI: 10.31558/2519-2949.2018.4.7.

7. Осин В. Наука в новом мире: Три сюжета генезиса региональной политологии в постсоветской Украине. Ab Imperio. Studies of New Imperial History and Nationalism in the Post-Soviet Space. 2015. №. 4. C. 239-293. DOI:10.1353/imp.2015.0085

8. Осин В., Зеленски А., Шуляк С. Власть и знание на постсоветском пространстве: политический режим, научная степень, идеология и карьера в Украине и Молдове. Вильнюс, 2014. 376 с.

9. Пірен М. Гендерні аспекти державної служби : монографія. Київ: «Основи», 2002. 335 с.

10. Rothman S., Kelly-Woessner A., Woessner M. The Still Divided Academy: How Competing Visions of Power, Politics, and Diversity Complicate the Mission of Higher Education. Rowman \& Littlefield Publishers, 2011. 282 p.

\section{References:}

1. Vyshcha osvita v Ukraini. Demohrafichna ta sotsialna statystyka / Osvita. Derzhavna sluzhba statystyky Ukrainy. URL: http://ukrstat.gov.ua/ (Access date: 11.05.2021)

2. Didukh H. Ya. Formuvannia imidzhu zhinky-politychnoho lidera : avtoref. dys. ... kand. polit. nauk : 23.00.02. Kyiv, 2010. $20 \mathrm{~s}$.

3. Zhurzhenko T. Gendernye rynki Ukrainy: politicheskaja jekonomija nacional'nogo stroitel'stva. Vil'njus: EGU, 2008. $256 \mathrm{~s}$.

4. Katan O. I. Kontseptualni y polityko-praktychni zasady vyrishennia gendernoi problemy v Ukraini : avtoref. dys. ... kand. polit. nauk : 23.00.02. Kyiv, 2005. $19 \mathrm{~s}$.

5. Litvin L. A. Osoblyvosti gendernykh doslidzhen u politychnii nautsi. Politolohichni zapysky. 2013. № 7. URL: http://nbuv.gov.ua/UJRN/Polzap_2013_7_18 (Access date: 19.06.2021)

6. Osin V. Ukrainska politolohiia v period feminizatsii: borotba «za» ta «proty» patriarkhatnoi epistemy. Politychne zhyttia. Vinnytsia, 2018. №4. S.44-51. DOI: 10.31558/2519-2949.2018.4.7.

7. Osin V. Nauka v novom mire: Tri sjuzheta genezisa regional'noj politologii v postsovetskoj Ukraine. Ab Imperio. Studies of New Imperial History and Nationalism in the Post-Soviet Space. 2015. №. 4. S. $239-293$. DOI:10.1353/imp.2015.0085

8. Osin V., Zelenski A., Shuljak S. Vlast' i znanie na postsovetskom prostranstve: politicheskij rezhim, nauchnaja stepen', ideologija i kar'era v Ukraine i Moldove. Vil'njus, 2014. $376 \mathrm{~s}$.

9. Piren M. Genderni aspekty derzhavnoi sluzhby : monohrafiia. Kyiv: «Osnovy», 2002. 335 s.

10. Rothman S., Kelly-Woessner A., Woessner M. The Still Divided Academy: How Competing Visions of Power, Politics, and Diversity Complicate the Mission of Higher Education. Rowman \& Littlefield Publishers, 2011. 282 p.

\section{Osin V. V. Gender Aspects of Higher Education in Political Science Communities in Ukraine and Moldova}

The article is devoted to revealing the gender aspects of higher education in political science communities in Ukraine (Lviv, Kharkiv, Simferopol) and Moldova (Chisinau) during 2012-2013.

This work is a part of a larger study which captures the state of Ukrainian political science during 20122013 and provides a better understanding of the political, social, ethnic, economic, gender and disciplinary views of students on the eve of the Revolution of Dignity. The empirical basis of this article is a survey of the students enrolled in three types of academic program (bachelor's, specialist's and master's degrees) at four universities: Ivan Franko National University of Lviv, V. N. Karazin Kharkiv National University, V. I. Vernadsky Taurida National University and Moldova State University.

The answers of the respondents allow to reveal several tendencies. Firstly, male and female students often face various forms of discrimination during their last years of study. Secondly, the percentage of female students who have faced various forms of discrimination in academia is higher than that of male students. Thirdly, it should be noted that in the vast majority of cases respondents report the individual nature of the discrimination they directly perceive, although the data may differ depending on the region and gender. Finally, male and female students were most often discriminated against on political grounds, which is probably understandable given the specialty, location and timing of the survey.

In the final part of the article it is concluded that in Ukrainian and Moldovan Academy the basic student level provides a better attitude to women than to men. Given that far more male students than female students agree with this statement, we can interpret this trend as a manifestation of patriarchy. That is, when female students do not see a better attitude but male students do, we are dealing with a hidden source of conflict.

Keywords: gender, regions of Ukraine, Moldova, history of political science, discrimination, patriarchy. 